\title{
Managing Diversity and Capabilities
}

\author{
PhD. Cand. Feriha Özdemir
}

\begin{abstract}
As a powerful driver, small and medium enterprises (SME) has a huge contribution to the German economy. The shortage of skilled workers underlines an emerging and resilient German economy. However, the future prospects of SME depend on creative employees as key actors. Nevertheless, demographic change is perceptible so that the labour integration of resident immigrants becomes more important. But several studies investigated inequalities especially discrimination in the labour market intensifying brain drain. Social discrimination has great impact on the capabilities of people, particularly in labour. Disadvantages are exposed to a lack of opportunities with the result of a capability gap. Diversity management offers competitive advantages but is mostly a management tool of bigger enterprise performances. This paper will present a process of enabling and empowering management process of capabilities. It is presented by the example of the solution cycle which will be called a participatory process design contributing to the lack in the classic management of diversity.
\end{abstract}

Keywords: Labour, inequalities, managing diversity, empowering, participatory process design.

\section{Introduction}

The technical potentials and the shift to a new economy have effects on social values and thus, when regarding workplaces, preferences and roles are changing. The German Federal Ministry of Labour and Social Affairs (BMAS 2015) contributes the term 'work 4. 0' in this respect. In the special case of German economy, its driving force is attributed to the powerful position of small and medium enterprises (SME) as the engine, of the German economy. About 99 per cent of the companies in Germany are SME which highlights their great significance for the economy (Destatis 2010). There are strong industries and successful services which are in demanded worldwide. Their special feature is that entrepreneurial actors and stakeholders take responsibility and are liable for the company's obligations with their assets. This follows the intention of Adam Smith (Cannan 1976, Eckl and Ludwig 2005). The study of Florida (2002) drew big attention on regional development by innovative promoters, viz. technology, tolerance and talents. According to Jacobs (1969) and Glaeser (2000), talents are the stimulators of economic development and innovation. In this context, a resilient economy resp. organization as well as their future prospects depend on an innovative development by key actors and creative employees. The rise of human creativity and diversity becomes a driving force and a key factor in the economy and society. In practice, however, rural and regiopolitan areas are suffering from brain drain movements. Following an OECD (2013) survey, nearly 90 percent of SME report shortage at medium skill areas and 65 percent in high skill areas. Both areas are expected to increase in the future which leads to the next challenge that is about retaining highly skilled staff and recruiting qualified employees.

Considering these circumstances, labour integration of disadvantaged groups, these are mainly women and resident immigrants resp. (new) Germans with migration background, become more important. However, several studies still highlight ethnic and gender inequalities especially discrimination and disadvantages in the labour market faced by women and migrants by unequal employment opportunities and career prospects. Women are still minorities in top positions (Holst, Busch-Heizmann and Wieber 2015). They hit the glass ceiling, an invisible barrier set up consciously or unconsciously by traditionally male-dominated ruling class, with the result that the German government introduced a 30 percent-quota for 
women on boards in 2016. Both mentioned groups do not have the best possible opportunities for development as they are not valued equally with the dominant groups in labour market.

Studies light out less success of particularly low-educated applicants especially in the case of migrants in the German labour market. In their study, Granato and Kalter (2001) describe the impact of the endowment with human capital to the job market position. Skilled staff with migration background seem more likely to be vulnerable experiencing discrimination than native applicants, especially in SME (Kaas and Manger 2012). Social and human capital of migrants has changed and their educational skills open up further opportunities in new markets. In Germany, approximately every fifth person is a migrant (Stadt Siegen 2013). To exclude people from labour according their capabilities would mean an expensive undertaking for a country like Germany.

Companies and organizations respond to the problem of discrimination and inequalities with a management strategy which is called Diversity Management. Diversity in organisations is concerned to different dimensions of human diversity and raised its significance in terms of becoming multicultural in a global world. It is claimed to change the organisational culture. Nevertheless, diversity management has the disadvantage to make differences of human beings visible. Now, the challenge consists of rethinking an approach that shows how management can enable human diversity and capabilities in companies. For that reason, this paper will present a process of enabling and empowering management process of capabilities. This is called managing capabilities and will be introduced by the process design of the so called Solution Cycle. The participatory process design, presented in this paper, contributes to the lack in the classic management of diversity that can be used by SME, too.

The rest of the paper is structured as follows: Inequalities in the labour market, diversity management, management in dynamic complexity and finally, conclusions.

\section{Inequalities in the labour market}

Discrimination is more than a distinction. It is mostly associated with unequal treatment or disadvantage. The influence to define social norms and codes, at least how discrimination is to be understood, may be described as the definitory power of a social system. Belonging to a particular social group flows in formation of a social identity.

There are two conducting neoclassical theories of discrimination which can be described as forms of hidden discrimination experiences of ethnic minorities. Firstly, discrimination is based on tastes or personal preferences (Becker 1971). All labour market actors try to maximize their profits and benefits, i. e. they ignore interactions with other economic actors with the result of paying costs. Secondly, discrimination is the result of employers' incomplete information (Phelps 1972) so that false group beliefs are imputed instead, e. g. competences of migrants are considered to be lower (Liebig and Widmaier 2009). "The notion of discrimination involves the additional concept that personal characteristics of the worker which are unrelated to productivity are also valued on the market. Such personal characteristics as race, ethnic background and sex have been frequently adduced in this context" (Arrow 1971, p. 1).

Despite of the previous theories, institutional mechanisms (e. g. trinomial German school system) have also negative impacts on the educational success of migrants which is described as institutional discrimination (Gomolla and Radtke 2009). Furthermore, structural discrimination arises from institutional regulated and formal policies and practices.

Ethnic inequality in the labour market has been investigated in various studies such as Kaas and Manger (2012), Damelang (2011), Granato (2003), Heath and Cheung (2007) and Platt (2011). It is commonly described that migrants have less success in the labour market.

Regarding gender, Agócs (2002) points out that female migrants deal with discrimination affected by sex and their ethnicity. With respect to ethnicity, a survey underlines that people with Turkish and Vietnamese origins face discrimination more often than people with Italian, Serbian and Croatian origin. Hence, it turns out to be difficult finding reasons for a 
disadvantage by a higher endowment of migrants with human capital (Plahuta 2007). An OECD study confirms that tertiary educated migrants are less successfully placed in the labour market than nationals especially in SME (Liebig and Widmaier 2009).

Self-fulfilling-prophecy. Considering the results of stereotypes and assumptions about members of a group release expectations that in turn may affect the behaviour of group members toward them, finally causes expectations to be fulfilled (Rosenthal 1995; Merton 1968; Watzlawick 2006). The risk of confirming negative stereotypes is called stereotype threat and impairs cognitive performance (Steele, Spencer and Aronson 2002). In various studies, the impacts of stereotypes have been investigated (e. g. Myers 2008; Bosson, Haymovitz and Pinel 2004).

To protect employees against discrimination, political reactions in Germany led to the introduction of a General Equal Treatment Act in 2006. A few years later, the Federal Anti-Discrimination Agency in Germany started an experiment with anonymous job applications with positive effects for applicants with different origins. Researchers picked up this result and developed a suitable system platform working with software which evaluates the competences of applicants (Bohlouli et al. 2013). Nevertheless, in the field of antidiscrimination and gender equality policy, Germany ranks 22nd on MIPEX (British Council und Migration Policy Group 2011). There are no available calculations about the costs of discrimination but economic costs by under-utilisation of human resources and brain waste can be assumed. Brain drain is an additional cost factor as well. The implementation of diversity promoting and including management strategies could save 21 billion Euro (Berger 2011) - this outcome should be handled with great care as the calculation of the number is not transparent.

Gender inequality and discrimination make it more difficult for women to participate in political, social and economic life. The International Labour Organisation (ILO 2012) reports that women worldwide are more affected by unemployment. Precarious employment of women has increased (Bispinck and Schulten 2011; see also Fudge and Owens 2006). The equality of opportunities between men and women in Germany lags behind its Scandinavian neighbours and Switzerland as countries with a high degree of gender equality (World Economic Forum 2013). In technology, women still belong to disadvantaged groups (Hewlett et al. 2008) and even in the Silicon Valley, there are diversity problems in terms of gender discrimination (Leas et al. 2015).

Steadily increasing part-time jobs are occupied by women with children. Women's policy of its neighbours is more active and progressive according to better compatibility of family and work (Luci 2011). Even if oppression and disadvantaging of women is older than capitalist systems, the whole economy with its top positions produces male monocultures (Holst and Busch 2010). Initiated by Dalla Costa (1973), feminist researchers emerged and brought the debate into the field of unpaid care and domestic work. The term of double socialization of women addresses the conflict between paid employment and unpaid and caring work at home (Becker-Schmidt 2002). As a result, women are discriminated in multiple ways, most of all in their ethnicity and the existence of family ties reducing flexibility.

\section{Diversity Management}

A widely known management tool to handle diversity and prevent discrimination in organizations is called Diversity Management (DiM). Its strategy is defined by promoting the implementation of diversity and heterogeneity in organizations. DiM is a part of the change and development in the organisation. Generally, diversity is characterised by four areas (Gardenswartz and Rowe 2002):

personality (e. g., traits, skills and abilities),

internal factors (e. g., gender, race, ethnicity, sexual orientation),

external factors (e. g., culture, nationality, religion, marital status),

organizational (e. g., position, department). 
In the 1980s, this approach was first used in the United States. Historically, it is rooted in the social unrests of the 1950s (Brazzel 2003). With the subsidiaries of US conglomerates, the idea came to Germany in the middle of the 1990s. The diversity of employees, cultures, strategies, functions etc. are used as a strategic resource to develop and solve complex challenges. Focused dimensions are visible features (e. g., gender, ethnicity, dress, age, race, physical attributes) and invisible ones (e. g., religion, skills, education, socioeconomic status, political views). Over the years, the following main concepts of diversity management have been developed (Thomas and Ely 1996):

Fairness and discrimination approach.

Access and legitimacy approach.

Learning and effectiveness approach.

All three concepts are not yet pleasing. The first and the second approach try to adapt the organization to changing environments but disregard the management view and internal integration. The third approach manages diversity internally. Actually, research projects about diversity management mostly reflect bigger companies' performances (Maxwell 2004, McDougall 1996, Sủß and Kleiner 2005 and Köppel et al. 2007). According to the results of Klaffke (2008), DiM is not yet known extensively at Hamburg's SME. In a study, the European Commission (2008) explored the creation of diverse workplace of SMEs across Europe. It is stated that SME are too small and consequently don't have the financial conditions for diversity management. Finally, DiM is a strategy mostly used in bigger organizational performances than SME. These findings appear to be consistent with the case study of SME in Siegen, a regiopolis in Germany (Özdemir 2014). DiM is not directly implemented resp. an unknown management strategy, however there is respect to gender, older and younger employees.

Positioning DiM as a part of the changing and developing process in organizations, there are various approaches discussed in management and organisational literature so far, among them Morgan (2006). Bolmann and Deal (2013) reframe the organization with the focus on four distinctive frames: structural (focusing on goals, effectiveness and task), human resources (behaviour and action), political (power, conflicts, influence) and symbolic or cultural (social interactions and symbols). On the political frame, the question of power and its distribution in organizations is emphasized here which is blinded-out in the conventional literature of DiM. According to further critical perspectives on DiM, Purtschert (2007) states that instead of considering social justice, DiM is much more focussing on maximizing the profits and thus, it is mainly reduced to economic efficiency variables (cost/benefit ratio).

The following part introduces this paper will present a process of enabling and empowering management of capabilities.

Management in dynamic complexity

DiM is known as a strategy to promote diversity and reduces disadvantages in organizations. Actually, it is seen in a critical light due to fact that diversity is recognized for economic reason and finally, to lift the corporate profits (business case). Bührmann and Schmidt (2014) propose to reform and change the frameworks in the company to fulfil the requirements of a good workplace. Newer management and organisational developing discussions especially for small and medium enterprises are less focussing on productivity increasing methods rather than the goal to develop a human and democratic management (Sattelberger, Welpe and Boes 2015). This approach will be affiliated so that in the following another way of management will be introduced that promotes peoples' capabilities. In their study of human capability reported in New Zealand workplaces, Byson and O'Neil $(2008,2009)$ point out various drivers and barriers of human capability in workplace that covers management as barriers, too. They produce a model of human capability development. Empowering people in terms of enlarging peoples well-being and agency will increase the opportunity to enlarge their achievements.

Developing human potentials vs. capabilities is the managers resp. leaders responsibility by creating supportive conditions and frameworks in the organizational context. Companies are subject of a dynamic complexity so that these turbulent 
systems can be characterized as organically, spontaneously and self-organizing. The main features of structures in this context are self-organisation and heterarchy. Organizations have to rethink about their future vitality that is a continued existence and further development by trying to design a manageable future in defining diversity as a chance. Conventional management approaches interpret companies as easy handling machines with obvious behaviour. With respect to the accelerated economic dynamism, the pressure for companies to innovate and change and to use human capital resources more effectively intensifies.

In this context, monocultural companies are past-orientated, too rigid and less able to learn from experiences and adapt accordingly with a lack of creativity and innovation. The particular challenge of management lies in a change of perspective to self-discovery, self-distance, empathy and xenophile (Bergmann and Daub 2012).

Following Ashby's law, also known as Law of Requisite Variety, we know that: "The larger the variety of actions available to a control system, the larger the variety of perturbations it is able to compensate" which creates challenges for the management (Ashby 1958). Following Lewin (1951), organizations can only be changed if their people also changes. To change an organisation is a process and all change is part of a learning process. DiM as a widely known management tool to handle diversity and prevent discrimination in organizations was presented. However, it is mostly used in bigger organizational performances than SMEs. It may offer competitive advantages but it is mainly reduced to economic efficiency variables.

This paper presents a concept to handle diversity beyond DiM in workplace. It is called the Solution Cycle (SC) and evolved from the systemic approach of management and several consulting works of Bergmann and Daub (2008) which primarily focuses on plurality and the integration of all actors in its first steps. Hence, the SC will be called a participatory learning process design towards a changing culture in organizations. According to Luhmann (1975), all organizations form social systems and constitute themselves by communicative actions which have decisive influence on the corporate culture of the systems. Effective and successful communication comes from within by active engagement in a dialogical corporate culture leading to corporate results. The contextual preconditions have to be created by the management and following the model of the SC it makes reaching decisions in dialogues more likely.

This theory is a process consisting of eight stages (Bergmann 2014): (1) recognizing, (2) clarifying, (3) creating, (4) structuring/evaluating, (5) changing, (6) assessing/experiencing, (7) learning and (8) flow. Managers can use this methodology in order to open their corporate culture to a diversity and capability friendly one.

\section{Figure 1: The Solution Cycle as a Process Design}

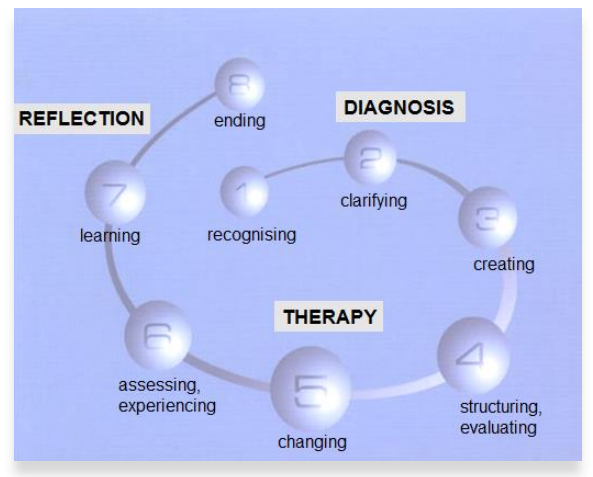

Source: Bergmann 2014, p. 23 
Every interaction of people begins with special occasions, a salutation or a welcoming speech. The first steps are defined by diagnosis of the current space and defining a common ground. It starts with recognising team members and relevant participants, a common description of the problem and arrangement on issues. Members of the same team might have different backgrounds and opportunities. On this account the manager has to place great importance on generating different views explained by diverse socio-demographic characteristics of team members at the beginning. That supports the project with a great deal of commitment.

Creating a common perspective on the task is possible by jointly clarifying the context and working on common rules. The second step is called the diagnosis constitution of a common ground which is the agreement on common goals, competences, visions and problems. Visions and guidelines serve the purpose of identification, orientation and development. Given the importance attached to this issue, the first steps require time and space (Bergmann and Daub 2006). Step three is about creating more opportunities, solutions and differences. Promoting creativity is likely by abduction; free zones causing team members to dissociate from the problem (Bergmann 2005). Well known creativity methods are e. g. usability, brainstorming, mind mapping, brainwriting, method 635, morphological boxes. After developing forward-looking ideas, team members evaluate and plan possible solutions together and come to common decisions.

Realizing a change in step five, one can intervene in the context, in actors or institution which is possible by changing 1. language/images (e. g., concerned and respectful interaction, positive expressions by changing the words), 2. design/architecture (e. g. pleasant working atmosphere), 3. structures in organization (e. g. flat hierarchies) and 4. managing of time (e. g., idleness, flexible working hours) (Bergmann and Daub 2008). Project members are invited to report and evaluate the results and praise or complain at the next stage. In the best-case scenario connection, participation and common decisions allow experiencing flow which leads at stage seven to patterns by reflecting and learning. Finally, the project comes to an end where all participants give final feedback. Team organization is founded on the motivation of the members by decentralized and participatory nature promoting success. The main task of the manager or facilitator is to provide new impulses and irritation, generating a framework by interactively developing standards and goals and creating fearless atmosphere where vitality and the overall development are gently enhanced. The development of a shared culture and conducive atmosphere for dialogues (Böhme 1995), communication, engagement, lasting relationships become more likely. People in flow are more friendly, cooperative, generous and happier (Csikszentmihalyi 2015). This management approach provides the possibility to integrate the heterogeneity in organizations. Particular importance is given to the manager in the role to guide a changing process and to form and create relationships to other actors, to the environment and other things such as products. Managing means creating and forming the context by intervening in the (a) language, images, culture, (b) time, (c) organization and rules, (d) rooms and spaces and (e) people (Bergmann and Daub 2012).

In conclusion, contextualizing capabilities in organizations depends on the caring commitment of people for other people and their environments. It is not possible to change people but a different behaviour of people is more likely. This can be reached by intervening in the frameworks and working conditions. Changes of images and language, design or architecture, structures in organization and flexibility in time increase the possibility for a different behaviour of people and their relationships. That is the message of the systemic approach (Baecker 2005; Simon 2004; Foerster 2002; Luhmann 2000) which is closely linked in this work.

\section{Conclusion}

This paper outlined that there are inequalities especially in the highly-skill section in the German labour market. Disadvantages are realized very often, recently demonstrated by two judgments of the European Court of Justice (ECJ Judgements 2011, 2012). Transferring Ashby's law, companies have to face impacts of pluralisation of life-styles with variety in order to stay attractive employers (Ashby 1958). The contingent world requires companies to raise the heterogeneity. Cultural mixed teams increase multiple perspectives in knowledge and learning exchange. Concerning the 
various challenges for companies and the shift to work 4.0 , labour integration, empowerment and promoting potentials are considered to be of big importance for resilient and innovative companies.

Diversity Management as a widely known management tool to handle diversity and prevent discrimination in organizations was presented. However, it is mostly used in bigger organizational performances than SMEs. It may offer competitive advantages but it is mainly reduced to economic efficiency variables (Krell 2015). For that reason, this paper presented a process of enabling and empowering management process of capabilities towards a changing culture in organizations that is based on the idea of cooperation and participation. Managing capabilities is compared with the idea of the systemic approach of management. In conclusion, contextualizing capabilities in companies depend on the caring commitment of people for other people and their environments. It is not possible to change people. However, the possibility becomes more likely by changing the framework and working conditions in the institutional and organisational context. Changing the context frameworks leads to a behavioural change of people and their relationships. The participatory process design presented in this paper contributes to the lack in the classic management and diversity management literature.

\section{References}

[1] Agócs, C. 2002. "Systemic Discrimination in Employment: Mapping the Issue and the Policy Responses". In Workplace Equality: International Perspectives on Legislation, Policy and Practice, edited by C. Agócs. The Hague: Kluwer Law International.

[2] Arrow, K. 1971. "The Theory of Discrimination". Working Paper 30A. Princeton: Industrial Relations Section.

[3] Ashby, W. R. 1958. "Requisite Variety and Implications for Control of Complex Systems". Cybernetica (Namur) 1(2): 83-99.

[4] Baecker, D. 2005. Schlüsselwerke der Systemtheorie. Wiesbaden: VS Verlag für Sozialwissenschaften.

[5] Becker, G. S. 1971. The Economics of Discrimination. Chicago: University of Chicago Press.

[6] Becker-Schmidt, R. 2002. Gender and Work in Transition. Globalisation in Western, Middle and Eastern Europe. Opladen: Leske \& Budrich.

[7] Berger, R. 2011. "Dreamteam statt Quote: Studie zu Diversity and Inclusion". Online: http://www. rolandberger. com/media/pdf/Roland_Berger_Diversitylnclusion_D_20110509.pdf. [Accessed 20. 5. 16]

[8] Bergmann, G. 2005. Gelingende Kommunikation ist Information. In Distinktion und Deutungsmacht, Studien zur Theorie der Public Relations, edited by L. Rademacher. Wiesbaden.

[9] Bergmann, G. and J. Daub. 2006. "Relationales Innovationsmanagement- oder: Innovationen entwickeln heißt Lernen verstehen ". ZfM: Zeitschrift für Management 2:112-140.

[10] Bergmann, G. and J. Daub. 2008. Systemisches Innovations- und Kompetenzmanagement. Wiesbaden: Gabler Verlag.

[11] Bergmann, G. and J. Daub. 2012. Das menschliche Maß - Entwurf einer Mitweltökonomie. München: Oekom.

[12] Bergmann, G. 2014: Die Kunst des Gelingens. Wege zum Vitalen Unternehmen- Ein Lehrbuch. Sternenfels: Verlag Wissenschaft \& Praxis.

[13] Bispinck, R. and T. Schulten. 2011. "Trade Union Responses to Precarious Employment in Germany". WSIDiskussionspapier 178. Düsseldorf: Wirtschafts- und Sozialwissenschaftliches Institut in der Hans-Böckler-Stiftung.

[14] BMAS, Federal Ministry of Labour and Social Affairs. 2015. "Green Paper. Work 4. 0". In: www. bmas. de [Accessed 6. 5. 16]

[15] Bohlouli, M, F. Ansari, Y. Patel, M. Fathi, M. L. Cid and L. Angelis. 2013. "Towards Analytical Evaluation of Professional Competences in Human Resource Management". IECON. Vienna.

[16] Böhme, A. 1995. Atmosphäre. Frankfurt/M.

[17] Bolman, L. G. and T. E. Deal. 2013. Reframing Organizations. Artistry, Choice, and Leadership. San Francisco: Jossey-Bass.

[18] Bosson, J. K., E. L. Haymovitz and E. C. Pinel. 2004. "When saying and doing diverge: The effects of stereotype threat on self-reported versus non-verbal anxiety ". Journal of experimental social psychology 40 (2): 247-255.

[19] Brazzel, M. 2003. "Historical and theoretical roots of diversity management ". In Beyond Awareness to Competency Based Learning, edited by D. L. Plummer, pp. 51-93. Handbook of Diversity Management. Lanham, MD: University Press of America.

[20] British Council and Migration Policy Group. 2011. Index Integration and Migration (MIPEX III). Brüssel.

[21] Bryson, J. and P. O'Neil. 2008. "Overview of findings on developing human capability “. Discussion paper. Victoria University of Wellington: Industrial Relations Centre. 
[22] Bryson, J. and P. O'Neil. 2009. "A workplace view of drivers and barriers to developing human capability". New Zealand Journal of Employment Relations 34 (1): 62-76.

[23] Bührmann, A. and M. Schmidt. 2014. Entwicklung eines reflexiven Befähigungsansatzes für mehr Gerechtigkeit in modernen, ausdifferenzierten Gesellschaften, edited by Friedrich Ebert Stiftung.

[24] Cannan, E. and A. Smith. 1976. An Inquiry into the Nature and Causes of the Wealth of Nations. Chicago: University Of Chicago Press.

[25] Csikszentmihalyi, M. 2015. Flow: Das Geheimnis des Glücks. Klett-Cotta.

[26] Dalla Costa, M. 1973. Die Frauen und der gesellschaftliche Umsturz. In Die Macht der Frauen und der Umsturz der Gesellschaft, edited by S. James, pp. 27-66. Internationale Marxistische Diskussion 36. Berlin: Merve.

[27] Damelang, A. 2011. Arbeitsmarktintegration von Migranten. IAB-Bibliothek 32. Bielefeld: Bertelsmann.

[28] Destatis. 2010. "Kleine und mittlere Unternehmen, Mittelstand ". Online: https://www. destatis. de. [Accessed 14. 04. 16]

[29] ECJ Judgements. 2011. 2012. Online: http://www. hensche.

de/Auskunftsanspruch_Stellenbewerber_Auskunftsanspruch_abgelehnten_Stellenbewerbers_Diskriminierung_EuG H_C415-10_Meister. html EPA. [Accessed 20.05. 16]

[30] Eckl A. and B. Ludwig. 2005. Was ist Eigentum? Philosophische Eigentumstheorien von Platon bis Habermas. München: C. H. Beck

[31] European Commission. 2008. "Turning Diversity into Talent and Competitiveness for SMEs ". http://ec. europa. eu, [Accessed 30. 06. 2016].

[32] Foerster, H. v. 2002. Einführung in den Konstruktivismus. München.

[33] Florida, R. 2002. The Rise of the Creative Class: And how it's transforming work, leisure, community and everyday life. New York: Perseus Book Group.

[34] Fudge, J. and R. Owens. 2006. Precarious Work, Women and the New Economy: The Challenge to Legal Norms. Onati International Series in Law and Society. Oxford, Portland Oregon: Hart Publishing.

[35] Gardenswartz, L. u. and A. Rowe. 2002. Diverse Teams at Work. Alexandria: Society for Human Resource Management.

[36] Glaeser, E. L. 2000. The new economics of urban and regional growth. In The Oxford handbook of economic geography, pp. 83-98, edited by C. Gordon, G. Meric and M. Feldman. Oxford: Oxford University Press.

[37] Gomolla, M. and F. O. Radtke 2002. Institutionelle Diskriminierung. Die Herstellung ethnischer Differenz in der Schule. Wiesbaden: VS Verlag für Sozialwissenschaften.

[38] Granato, N. and F. Kalter. 2001. "Die Persistenz ethnischer Ungleichheit auf dem deutschen Arbeitsmarkt. Diskriminierung oder Unterinvestition in Humankapital? " Kölner Zeitschrift für Soziologie und Sozialpsychologie 53 (3): $497-520$.

[39] Granato, N. 2003. Ethnische Ungleichheit auf dem deutschen Arbeitsmarkt. Schriftenreihe des Bundesinstituts für Bevölkerungsforschung. Band 33. Opladen: Leske \& Budrich.

[40] Heath, A. F. and S. Y. Cheung. 2007. Unequal Chances: Ethnic minorities in western labour markets. Oxford: Oxford University Press.

[41] Hewlett, S. A., C. B. Luce and L. J. Servon. 2008. "The Athena Factor: Reversing the Brain Drain in Science, Engineering, and Technology". Harvard Business Review Research Report. Harvard.

[42] Holst, E. and A. Busch. 2010. Führungskräftemonitor. Berlin: DIW.

[43] Holst, Elke, A. Busch-Heizmann, A. Wieber. 2015. Politikberatung kompakt. 100. Fuihrungskrafte-Monitor 2015 Update 2001 - 2013. Berlin: DIW.

[44] International Labour Organisation (ILO). 2012. Global employment trends for women. Geneva.

[45] Jacobs, J. 1969. The Economies of Cities. New York: Random House.

[46] Kaas, L. and M. Manger. 2012. "Ethnic Discrimination in Germany's Labour Market: A Field Experiment". German Economic Review 13 (1): 1-20.

[47] Klaffke, M. 2008. "Vielfalt als Wettbewerbsfaktor nutzen: Diversity Management in Hamburg; Ergebnisse einer Unternehmensbefragung". Working Paper Series der HSBA Hamburg School of Business Administration 1. Hamburg.

[48] Krell, G. 2015. Kritik an Gender und Diversity - Gender und Diversity als Kritik:

[49] Das Beispiel Betriebswirtschaftslehre. In Diversität, Diversifizierung und (Ent)Solidarisierung. Eine Standortbestimmung der Diversitätsforschung im deutschen Sprachraum, edited by E. Hanappi-Egger and R. Bendl. Wiesbaden: Springer VS.

[50] Köppel, P., J. Yan and J. Lüdicke. 2007. Cultural Diversity Management in Deutschland hinkt hinterher. Gütersloh: Bertelsmann. 
[51] Leas, M., J. Oberweis, T. Vassallo, E. Levy, M. Madansky, H. Mickell and B. Porter. 2015. "Elephant in the Valley". Stanford University. In: http://www. elephantinthevalley. com [Accessed 20. 06. 2016].

[52] Lewin, K. 1951. Field Theory in Social Science. New York: Harper and Row.

[53] Liebig, T. and S. Widmaier. 2009. "Children of Immigrants in the Labour Markets of EU and OECD Countries: An Overview". OECD Social, Employment and Migration. Online: URL: http://www. oecd. org/ dataoecd/62/35/43903354. pdf. [Accessed 17. 2. 16]

[54] Luhmann, N. 1975. Interaktion, Organisation, Gesellschaft. Anwendungen der Systemtheorie. In Soziologische Aufklärung. Bd. 2. Aufsätze zur Theorie der Gesellschaft, pp. 9-20. Opladen.

[55] Luhmann, N. 2000. Organisation und Entscheidung. Wiesbaden: Opladen.

[56] Luci, A. 2011. Frauen auf dem Arbeitsmarkt in Deutschland und Frankreich. Berlin: IAB.

[57] Maxwell, G. A. 2004. "Minority report: taking the initiative in managing diversity at BBC Scotland". Employee Relations 26 (2):182-202.

[58] McDougall, M. 1996. "Equal Opportunities versus Managing diversity: Another challenge for Public Sector Management?". International Journal of Public Sector Management 9 (5/6): 67-72.

[59] Merton, R. K. 1968. Social Theory and Social Structure. New York: Free Press

[60] Morgan, G. 2006. Bilder der Organisation. Stuttgart: Klett-Cotta.

[61] Myers, D. G. 2008. Psychologie. Heidelberg: Springer.

[62] OECD 2013. Recruiting Immigrant Workers: Germany 2013. Paris: OECD Publishing. Online: http://dx. doi. org/10. 1787/9789264189034-en. [Accessed 10. 12. 13].

[63] Özdemir, F. 2014. "Transcultural contexts and management challenges: Ethnic inequalities in German labour market. "International Journal and Economics and Finance Studies 6 (2): 13-24.

[64] Phelps, E. S. 1972. The Statistical Theory of Racism and Sexism. The American Economic Review, 62, 4, 659-661.

[65] Plahuta, S. 2007. Die Integration von Menschen mit Migrationshintergrund in städtische Arbeitsmärkte - dargestellt am Beispiel der Stadt Stuttgart. Wirtschaftsgeographie Band 42. Berlin: LIT Verlag.

[66] Platt, L. 2011. Understanding Inequalities: Stratification and Difference. Cambridge: Polity.

[67] Purtschert, P. 2007. "Diversity Management: Mehr Gewinn durch weniger Diskriminierung? Von der Differenz im Umgang mit Differenzen ". In Femina Politica 1/2007: 88-96.

[68] Rosenthal, R. 1995. "Critiquing Pygmalion: A 25-year perspective ". In Current Directions in Psychological Science. Band 4.

[69] Sattelberger, T., I. M. Welpe and A. Boes. 2015. Das demokratische Unternehmen: Neue Arbeits- und Führungskulturen im Zeitalter digitaler Wirtschaft. Freiburg: Haufe,

[70] Simon, F. B. 2004. The Organisation of Selforganisation. Heidelberg: Carl-Auer-Verlag.

[71] Stadt Siegen. 2013. "Zensus". Online: http://www. siegen. de/standard/page. sys/details/eintrag_id=6168/content_id=6397/25. htm. [Accessed 27. 04. 16].

[72] Steele, C. M. ; S. J. Spencer and J. Aronson. 2002. "Contending with Group Image: The Psychology of Stereotype and Social Identity Threat ". Advances in Experimental Social Psychology 34: 379-440.

[73] Süß, S. and M. Kleiner M. 2005. "Diversity-Management in Deutschland: Ergebnisse einer Unternehmensbefragung". Arbeitsbericht 17. Hagen.

[74] Thomas, D. A. and R. J. Ely. 1996. "Making Differences Matter: A New Paradigm for Managing Diversity". Harvard Business Review 74 (5): 79-90.

[75] Watzlawick, P. 2006. Anleitung zum Unglücklichsein. München: Piper.

[76] World Economic Forum. 2013. "Global Gender Gap Index". Online: https://www. weforum. org [Accessed 15. 04. 16] 